\title{
Without a voice, with a violated body: Re-reading Judges 19 to challenge gender violence in sacred texts
}

\section{Madipoane Masenya (ngwan'a Mphahlele) ${ }^{1}$}

\begin{abstract}
Although they are a majority of the South African population, African women in South Africa remain on the periphery of the margins of our communities. They are women who, although are a majority, mostly remain without a voice. Does it occasion any surprise then that they continue to be the face of violence in our contexts? It is a fact that the present South African landscape is characterised by, among other social evils, the violent acts perpetrated against women and children. That South Africa ranks among the leading countries in the world with appalling statistics on violence against women is well known. Such violence against a section of the South African population is entrenched by, among others, pronounced patriarchies, female voicelessness, dangerous masculinities and violent biblical hermeneutics. The latter hermeneutics is buttressed by some violent sacred texts interpreted in our predominantly patriarchal contexts. The present article seeks, among others, to bring a voice to the muted voice of the pilegesh in the text of Judges 19 by challenging gender-based violence both in the biblical text and in the African-South African context.
\end{abstract}

Keywords: Bosadi (womanhood) approach, female voicelessness, piligesh, the Levite, Judges 19, African-South African women, Judges 19, gender based injustice.

\section{Introduction}

In our everyday lives, those who possess a voice are those on top, those with power. Such people occupy the upper layers of our societal pyramids. Conversely, those at the bottom of our societal pyramids are usually voiceless, with no legitimated power, like women in a patriarchal context. Based on the latter example, it can be argued that there is a link between voicelessness, gender-based violence and marginalisation. A good example of a text that reveals the link between voicelessness, gender-based violence and marginalisation is Judges 19 in the Hebrew bible. In keeping with the theme of the colloquium on religious, ethical and theological voice and voicelessness, also informed by the violent context in which all South Africans, and in particular, African women in South Africa find themselves, I have elected to re-read the text of Judges 19 from a gender-sensitive perspective in order to challenge the violence that is depicted in that particular text. I will employ the bosadi approach towards such an analysis.

1 Prof. M.J. Masenya (ngwan'a Mphahlele) is a Professor of Old Testament Studies in the Department of Biblical and Ancient Studies, University of South Africa. She can be contacted at masenmj@unisa.ac.za 
As a point of departure, I will give a brief explanation of the bosadi approach. This will then be followed by the narration of Judges 19, particularly informed by the theme of voicelessness in the context of gender-based violence. Some observations derived from the re-reading of the text will then be given.

\section{The bosadi approach}

The Northern Sotho (Sepedi) word "bosadi" [womanhood] is an abstract noun. It comes from the word "mosadi" with the meaning "woman", "married woman" and "wife" (Ziervogel and Mokgokong 1975:1154; Brown 1979:217). The word "mosadi" has "-sadi" as its root, which has to do with womanhood. The word "bosadi", for example, may be translated as "womanhood" or a "woman's genitals". The noun "bosadi" is a Sotho word (Northern Sotho, Southern Sotho and Setswana), and has its counterparts in other African-South African languages as in the following examples: "musadzi" (Tshivenda), "wansati" (Xitsonga) and "umfazi" (isiZulu). In the traditional patriarchal sense of the word, "bosadi" describes what it means to be a woman in the African-South African (Northern Sotho) culture.

In the context of biblical studies, a bosadi approach examines what ideal/liberative womanhood should be for an African-South African woman bible reader. The approach aims at challenging disempowering notions of womanhood as embedded in African cultures. The approach includes the following elements:

(a) a critique of the oppressive elements of African culture evident in women's lives, while reviving aspects that uplift the status of women;

(b) a critique of the oppressive elements of the Christian bible, while highlighting the liberative elements - although the bible is a product of patriarchal cultures, it does contain liberative elements, if read from a gender perspective;

(c) the interplay of post-apartheid racism, sexism, classism, and the African culture as significant factors in the context of an African-South African woman, factors that in one way or another shape women's reading of the bible;

(d) the concept of botho/ubuntu; and

(e) the significance of the family for Africans.

According to Goduka (1995:2), the botho/ubuntu concept rests on the African proverb and is an integral part of all African cultures and languages spoken in South Africa - the Northern Sotho version is Motho 
ke motho ka batho, which means "A human being is a human being because of other human beings." Goduka continues:

The communality, collectivity and the human unity implicit in the proverb operates in the philosophical thought of African peoples. It is the guiding principle for relating with other people. It also forms a basis for thinking, behaving, speaking, teaching and learning, and is devoted to the advancement of human dignity and respect for all. Taking the botho/ubuntu concept seriously implies that the liberation of all African women in South Africa calls for the involvement of all Africans (both women and men) and the involvement of all South Africans.

The significance of the family for Africans, which is also highlighted by the bosadi concept, is of such sociological importance that it cannot be overemphasised. A gender-sensitive perspective that undermines the family and family-oriented matters is not balanced. However, neither man nor woman is supposed to be bound to the family. It should be the responsibility of all South Africans - both black and white, men and women, poor or rich, gay or straight - to promote the spirit of communality.

From the preceding analysis, it has hopefully become evident that a mosadi within the bosadi framework, will, unlike the traditional African mosadi, not be a voiceless woman who allows her voice to be muted by anyone, including all life-denying peoples and systems. A bosadi reading of Judges 19 will hopefully bring voice to the plight of the voiceless woman depicted in there by challenging the gender-based violence perpetrated on the woman who, although she had a body, was not given a voice. The giving of voice to such characters can only benefit our contexts, be it academic or ecclesiastical, that continue to remain almost silent about challenging gender-based violence.

\section{The narration in Judges 19}

The characters in Judges 19 are nameless. To an extent, they become the victims of the narrator's narration, thus adding to their invisibility. One of the characters is an unnamed Levite who had a concubine wife from Bethlehem. The Levite's concubine, whose story the present paper seeks to foreground, thus shares the victimisation of namelessness with all other characters in the story, though in her case she is also typified by voicelessness. In this regard, Bohmbach (1999:88) says:

The woman's relative non-presence in verses $10-15$ is effected additionally by the fact that she has no name and no voice, either in this episode, or elsewhere in Judges 19. In having no voice, though, she ends up standing in sharp contrast to the male characters, all of whom talk at some point in the story. 
As we read Judges 19:2 and 19:19, we may speculate that the Levite was not a poor man because he had in his possession a servant, at least more than one wife (although the story focuses only on the concubine wife), and the resources that would make him and his company not to burden the host in Gibeah. Reis (2006:146) goes beyond the issue of victimisation to see the story reflected in Judges 19 as portraying the depravity of Israel when she says:

The technique of namelessness illustrates the disintegration and dehumanization of society while it universalizes the characters in this sordid story. The Levite, the father, the old host, and the men of Gibeah are paradigmatic perpetrators, unforgivable, earning and deserving the contempt of history. And the nameless woman, immortalized, represents every victim — man, woman, or child — of the tyranny of the strong over the weak.

From the text, we obtain the impression that the Levite had a squabble with his concubine. Translators, also influenced by the differing Masoretic Text's and the Septuagint's rendering of the word "zānâ" (Judg. 19:2), differ regarding the reason that the woman decided to leave the Levite. To this, I will later return. The meaning of the Hebrew word "pilegesh" is concubine. The word refers to a wife of secondary status in some Old Testament texts (Gen. 16). What is tricky about the pilegesh of Judges 19 is that although the narrator chooses to use this word rather than the word "ishah", which is the legitimate word used for wife, it appears that she was not an ordinary pilegesh. This is buttressed by the observation that the word "neerah" can be translated as "newly married woman". In addition, the pilegesh's father is referred to as "hatoh" or "hatan", which literally means, "he who has a son-in-law", that is, a father-in-law in relation to the pilegesh's husband, the Levite. I therefore choose to translate the word "pilegesh" as "a legitimate wife", one of the wives of the Levite. ${ }^{2}$ Given the (harsh) treatment that the pilegesh of Judges 19 receives from her husband, in my African-South African context, a pilegesh would probably resemble one of the older wives of an African polygynist. In this cultural context, the older the wife in a polygynous marriage relationship, the less attention (secondary status?) she receives from her husband, not to the extent though of being seized by the mob for mass rape! Also, in this social setting, such a wife would have some voice, unlike the voiceless pilegesh of Judges 19.

As already noted, a challenge facing the translators of verse 2 is the Masoretic Text's rendering of the reason that the pilegesh decided to desert the Levite. In my view, Exum (1988:260) is correct in arguing that citing harlotry (in accordance with the Masoretic Text's rendering of verse 2) and translating the Hebrew word "zanah" to mean to have an illicit sexual intercourse as the cause of the pilegesh leaving her husband, makes no sense in the present

2 For a more elaborate explanation of this word, refer to an article on the use of this word with reference to Hagar, the pilegesh/concubine wife of Abram in Genesis 16 (Masenya (ngwan'a Mphahlele) 1998). 
textual context. Such a translation depicts the pilegesh as a serious offender because the sexuality of wives was owned by their husbands in that context. Such ownership of women's sexuality by men is also typical in the African-South African context, a fact that is not unrelated to the gender-based violence that is rife in this particular context. In a context in which the wife was the husband's property, in which adultery committed by a married woman was punishable by death, the secondary nature of the pilegesh's marital status, the humiliation that the pilegesh's father and her husband would experience when shamed by a woman of her status, it makes no sense that she could flee to her father's house carrying the guilt and shame of prostitution (see Boling 1975:273-274). Could a Levite, who was well versed in the law, run after a woman who had committed such a shameful act? Bohmbach (1999:90) observes that on account of the preceding (con)textual lapses in terms of logic, many scholars are persuaded to follow the Greek and Old Latin versions and their translation of the text as "she became angry with him" (see Boling 1975:273-274). I thus agree with Holladay's (1971:90) translation of the verb "zanah" in its qal imperfect yiznah to mean "feel a dislike for". The Levite most probably offended his wife so much that she "became angry with him" (NRSV), and decided to seek refuge in her father's house. If we follow the rendering that the designation "neerah" in this textual context means "a newly married woman", could it have been an early divorce?

In my view, the observation that he pursued her in order "to speak tenderly to her and bring her back" (Judg. 19:3) reveals that the Levite, rather than his wife, is the perpetrator of whatever led to the pilegesh's decision to desert him.

What is surprising though is the hospitality that the Levite received from his father-in-law. The rules of hospitality in those days notwithstanding, the hospitality revealed in the present text appears to be exaggerated. The situation not only hints at the host's manipulation of the guest, but also it reveals the inability of the Levite to make a sound judgement. What the traditional African-South African woman readers of the narration will find amazing with regard to hospitality as revealed in this text is the invisibility and absence of the mother (the Levite's mother-in-law in this case) in the house because hospitality in their context was essentially shown by women. With a woman being the manager, mother and carer in the patriarchal Israelite household (Meyers 1983:569-593), we may speculate that she would probably have fared better in terms of wisdom, compared with the male hosts depicted in Judges 19. However, in the bosadi view of things, both women and men need to be involved in all household chores, including the practice of hospitality. In that way, the corporeal mentality of African peoples would be enhanced, while African women would be relieved from the full load of household chores. In ancient Israel, hospitality was 
nevertheless mainly shown by men (the narrator of Judg. 19 who presents a man [host] hosting another man/men), although the important tasks of food preparation were performed by women.

Noteworthy for the theme of the present article is that thus far in the narration of the story the body of the pilegesh is visible to the reader in verse 2. A mosadi reader will be fascinated by the pilegesh's capacity to make a decision and resist injustices done to her as can be deduced from this verse: "But his concubine became angry with him, and she went away from him to her father's house at Bethlehem in Judah, and was there some four months." The pilegesh thus remains this character with a body but without a voice. A mosadi reader of this story is disturbed by the voicelessness of the woman, who actually took the first steps in the first instance. Sheldon (1997:9) is right when she says, "Though she is the centerpiece of the story (all the events and issues affect her or are affected by her in some way) she herself does not speak, nor does she behave on her own, until that fateful hour."

In verse 10 , the Levite and his concubine are portrayed as starting the journey together. Has she decided to forgive her husband after four months of having deserted him? Or was it mainly the decisions of the two men whose story of hospitality we as present-day readers have been allowed to hear so far? On account of her voicelessness and powerlessness, we can only surmise that the decision to return to the offender was probably made on her behalf. Or could it be that, indeed, the Levite succeeded in speaking kindly to her (Judg. 19:3)? A mosadi reader may not be surprised, though not impressed, by the pilegesh's return to violence, given the reality of many African-South African women who choose to remain in violent relationships/partnerships for economic, cultural, or religious reasons, among others.

As the day was far spent, the Levite's servant advised that the three travellers seek hospitality in the nearby city of the Jebusites (Judg. 19:11). Not heeding the sound advice of a fellow man, albeit with a lower social status, and on account of his intolerance for the non-Israelites, the Levite pushed the company to carry on with the journey. To the Levite's disappointment, the three could not find any hospitality in Gibeah. Instead, an old Ephraimite man residing in Gibeah (Judg. 19:20) offered to host them. Unfortunately, their merriment and hospitality did not last long because they were interrupted by a mob, "a perverse lot" whose command to them is reminiscent of the words of the men of Sodom to Lot's male guests in Genesis 19:8: "Bring out the man who came into your house, so that we may have intercourse with him." (Judg. 19:22). The host did not hesitate to reveal his willingness to grant them an offer in terms of their mission to have intercourse with a person. In the old man's view, the person's sex though had to be different: "No, my brothers, do not act so wickedly. Since this man is my guest, do not do this vile thing." (Judg. 19:23). The old man went on to offer the voiceless and powerless others, the women! "Here 
are my virgin daughter and his concubine; let me bring them out now. Ravish them and do whatever you want to them; but against this man do not do such a vile thing." (Judg. 19:24). The voiceless do not have a share in the decision even of their fate! Bach (1998:8) rightly argues:

Women, even violated ones, are as silent, compliant, as uninvolved as the narrator understands them to be. For in biblical law, rape is a crime against the father or husband of a woman. A woman has no right to initiate a trial.

What appals a mosadi reader of this horrifying passage is the apparent gendered act of hospitality displayed in Judges 19. Was it fine if what the old man referred to as "this vile thing" was perpetrated on the pilegesh and not on the Levite? Were both of them not his guests? If the innocent virgin daughter and the pilegesh, those characters who remain voiceless, were to be sexually assaulted by these strangers, would that not be a vile thing? Who then has a voice on what proper sexuality should entail? Had the mob demanded to have sexual intercourse with the servant of the guest, would the host have responded in the same way? A two-fold irony is narrated in the following verses: the guest, not the host, is the one who "offers hospitality" to the perverse mob: he seized his own wife, who was also a guest, and put her out to them! One who was supposed to find a home, not only as a guest in the old man's home, but more importantly with the man she had fled from four months before, was thrown outside of the comfort of the home to be assaulted sexually - the worst of all forms of sexual assaults: she was gang-raped the whole night! All these occur in the midst of voicelessness on the part of the victim.

As if the Levite was not satisfied with the torture to which he had exposed his wife, an exercise far removed from his earlier intention "to speak tenderly to her and bring her back" (Judg. 19:3), the first words with which the wife is greeted only reveal how rude and heartless the Levite was (or the Levite's portrayal by the pro-Josianic Deuteronomist?): "Get up", he said to her, "we are going." Receiving no response from her, the Levite put the pilegesh on the donkey. Could it be that there was a permanent voicelessness on account of the physical death of the pilegesh? Commentators differ regarding the exact point at which the pilegesh died. Upon entering his house, the Levite cut the body of the pilegesh into twelve pieces, limb by limb, and sent it throughout all the territory of Israel, saying: "Thus shall you say to all the Israelites, 'Has such a thing ever happened since the day that Israelites came up from the land of Egypt until this day? Consider it, take counsel and speak out." ".

At the conclusion of the preceding narration, one cannot but agree with Trible (1984:65) that:

The betrayal, rape, torture, murder, and dismemberment of an unnamed woman is a story we want to forget but are commanded to speak. It speaks of the horrors of male power, brutality and triumphalism; of 
female helplessness, abuse and annihilation. To hear this story is to inhabit a world of unrelenting terror that refuses to let us pass by on the other side.

The pilegesh's is the story we want to remove from our memories, perhaps even from the sacred text had we the power to do so. The pilegesh is one of those biblical characters to whom we reluctantly wish to give a voice, as is usually the case with so many rape victims in the African-South African context. However, as justice-seeking biblical scholars and theologians, we dare not! Not when our twenty-first century contexts continue to be typified by women's invisibility, voicelessness and violent acts perpetrated against women and children. Motsei (2007:19-20) observes:

The escalating rate of sexual violence in South Africa is alarming. The increasing occurrence of rape is not only worrying; the fact that the assaults are also accompanied by vicious sadism and gross mutilation of women's bodies is of deep concern. Many women's organizations reveal that most incidents of sexual violence go unreported. We know from the recent 1 in 9 campaign that for every woman who reports rape, nine others are silenced by fear, shame and guilt.

Informed by the African-South African context, how can we respond to such a violent biblical text? How can we re-read and re-hear the story of the unnamed voiceless pilegesh of Judges 19 in an attempt to challenge gender-based violence in this particular text and, hopefully, in our context(s)?

\section{The women at the bottom of the ladder of victims}

Judges 19 does not reveal only the male-female power dynamic, since other dynamics of power, such as social class, male-male (power) relations, and status, also occur (see Jones-Warsaw 1993:126-142). Therefore, to interpret the whole text of judges 19 corpus Judges 19-21, which is the conclusion to the book as solely portraying the power dynamics between males and females with the latter always emerging as victims of men is to underestimate other power dynamics notable in this text. However, if we cast a bosadi gaze on the text, we can argue that irrespective of these other power dynamics, females remain at the bottom of the ladder of victims as the following examples will clearly demonstrate.

\subsection{Voiceless and nameless characters}

That the narrator chooses not to name all characters (irrespective of their sex), thus creating a distance between him and them, shows that injustice is not only done to the female characters, the pilegesh and the virgin daughter, but to the male characters too (Bal 1999; Yoo 1997:41; Coetzee 2002:55). As is the case in a patriarchal world though, the females are not named by their personal names but in terms of their relationship to their male patrons, thus victimising them even more. The host's virgin daughter should have been 
regarded as a valuable asset to her father, as her dowry was supposed to be consistent with her virgin status, while the pilegesh, a woman in marriage - an esteemed institution in those days and in the African-South African context today, was regarded as a legitimate wife, albeit of a secondary status. In my view, women should be free to choose the form of identity with which they are comfortable. Informed by the bosadi concept, such an identity may be man-less and yet affirming. In the present text, female identities reflect something of male control of women's sexuality, something that needs to be challenged.

\subsection{Female sexuality, the object of male control}

From the text of Judges 19, it has become clear that men as patrons, depending on their particular relationships to the females in question, have control over female bodies. Nameless and voiceless, even their sexuality was under the control of a virgin girl's father and a wife's husband. Does it occasion any wonder then that the old man did not think twice to offer the two females, her daughter and her female guest, to the perverse lot? Similarly, we are not surprised that the Levite could, against the will of his pilegesh, seize her and throw her out to the mob! He could do as he liked with his property, particularly this one who had had the courage to desert him. Such control over female sexuality is revealed in our African-South African context by the underlying mentality behind some of the indigenous proverbs. Once a woman is in marriage, her sexuality belongs to her husband only. Not the other way around though. One example of such a proverb is Monna ke thaka, o a naba [A man is a pumpkin plant, he spreads]. Its tenor reveals that a married man can have other sexual partners outside his marriage. When under pressure, the Levite in Judges 19 "forgot" that he was the only rightful owner of his pilegesh's body. He seized her and threw her outside to be ravaged sexually by strange Israelite men! With such a one-sided control over female sexuality, reinforced by the power and privilege given to men in a patriarchal context, and the hermeneutics of silence regarding gender-based violence, it only makes sense that there are many instances of sexual violence in our contexts, even within what is supposed to be the safety of our homes and churches. Motsei's (2007:19) remark in this regard is worth noting:

Unlike racism, however, sexist practices are perpetrated not only by strangers but also by those with whom women live intimately. The fact that the home is one of the institutions in society that reinforce deeply entrenched sexist beliefs presents a major challenge to efforts aimed at rooting out sexism. It is in the home that some of the most brutal forms of violence and torture are perpetrated against those perceived to be weak, i.e. women and children. It is no wonder that a greater proportion of women who are raped are violated not by strangers but by someone they know and trust in the "safety" of their 
own homes. Contrary to popular belief, the home is not necessarily a safe place for women and children.

Informed by the preceding words, and the gender-based violence in our context, we are not so surprised that the male act of seizing the pilegesh to give her as a rape sacrifice came from what was supposed to be the comfort of the home! In our violent context, such victims remain with their violated bodies and without a voice.

\subsection{Women: Bodies without a voice}

The Levite's father-in-law manipulates his guest, the son-in-law, by persuading him to stay longer than he had apparently intended. Fewell and Gunn (1993:132) question whether this delay arises from the host's concern about his daughter's possible mistreatment at the hands of the Levite or his delight at seeing his son-in-law.

Yee (1995:162) opines that "[C]ross-cultural studies point out that the host-guest relationship is essentially one of unequal power relations. The flamboyant display of generosity by the father-in-law toward the Levite symbolises the moral and conceptual subordination of the guest to the host."

As previously noted, the pilegesh, who in my view was supposed to be the key role-player because her action led to the Levite's visit to her father's house, is conspicuous by her voicelessness. Not only was she invisible by her lack of name, but also by her silence. This was probably an imposed voicelessness. Silenced all the way through, even when she was thrown out to the rapists! This was clearly not silence by choice. Being surrounded by foreigners to her sex, thus a stranger in a patriarchal setting, the (strange) male narrator chose to deprive her of a voice even in the context of what can be designated an event akin to serial murder. The unnamed woman of Judges 19 is, like many other rape victims in our contexts, a violated body, without a voice at the bottom of the ladder of victims.

\section{Conclusion}

My bosadi analysis of the text of Judges 19 has hopefully revealed the reality of the existence of painful, violent texts in the bible. Such texts are usually not brought to the attention of our bible-reading communities even though they usually serve to endorse patriarchy and misogyny by those to whom patriarchy affords a voice. My engagement with the story of the voiceless pilegesh has hopefully exposed androcentric, misogynistic ideologies embedded in the biblical texts and in our violent contexts. I have ventured to touch the untouchable by giving voice to violated characters in the biblical text. By doing so, I hope to give voice to the voiceless and violated others, not only within the pages of our sacred texts but also in our violent contexts. The story of the pilegesh is a reminder to the voiceless, those with violated bodies, that it remains the desire and delight of their Potter to see them back together again. 


\section{References}

Bach, A. 1998. Rereading the body politic: Women and violence in Judges 21. Biblical Interpretation 6(1):1-19.

Bal, M. 1999. Dealing/with/women: Daughters in the Book of Judges, in Women in the Hebrew bible: A reader, edited by A. Bach. London: Routledge:317-333.

Bohmbach, K.G. 1999. Conventions/contraventions: The meaning of public and private for the Judges 19 concubine. Journal for the Study of the Old Testament 24(83), June:83-98.

Boling, R.G. 1975. Judges: Introduction, translation and commentary. Garden City, N.Y.: Doubleday.

Brown, J.T. 1979. Setswana dictionary: Setswana-English and English-Setswana. $3^{\text {rd }}$ edition. Johannesburg: Pula Press.

Coetzee, J.H. 2002. The "outcry" of the dissected woman in Judges 19-21: Embodiment of a society. Old Testament Essays 15(1), January:52-63.

Exum, J.C. 1988. The Book of Judges, in Harper's bible commentary, edited by J.L. Mays. San Francisco, Calif.: Harper \& Row:245-261.

Fewell, D.N. and Gunn, D.M. (eds.) 1993. Gender, power, and promise: The subject of the bible's first story. Nashville, Tenn.: Abingdon Press.

Goduka, J.T. 1995. A manual to empower educators to affirm diversity. (Unpublished study material).

Holladay, W.L. 1971. A concise Hebrew and Aramaic lexicon of the Old Testament. Leiden: Brill.

Jones-Warsaw, K. 1993. Toward a Womanist hermeneutic: A reading of Judges 19-21, in A feminist companion to Judges, edited by A. Brenner. Sheffield: Sheffield Academic Press:126-186.

Masenya (ngwan'a Mphahlele), M. 1998. A Bosadi (womanhood) reading of Genesis 16. Old Testament Essays 11(2), July:271-287.

Meyers, C. 1983. Procreation, production and protection: Male-female balance in early Israel. Journal of the American Academy of Religion 51(4), December:569-593.

Motsei, M. 2007. The kanga and the kangaroo court: Reflections on the rape trial of Jacob Zuma. Sunnyside: Jacana.

Reis, P.T. 2006. The Levite's concubine: New light on a dark story. Scandinavian Journal of the Old Testament 20(1):125-146.

Sheldon, J. 1997. Reading the bad in our story: A prerequisite to redemption. A study of Judges 19-21. (Paper read at the Adventist Society for Religious Studies meeting in San Francisco, Calif., United States, 22-25 November 1997). http://www.aaw.cc/PDF_files/Sheldon\%20Concubine\%20Jdg19-21\%20_2_.pdf [accessed 22 Nov. 2012].

Trible, P. 1984. Texts of terror: Literary-feminist readings of biblical narratives. Philadelphia, Pa.: Fortress Press.. 
Yee, G.A. (ed.) 1995. Judges and method: New approaches in biblical studies. Minneapolis, Minn.: Fortress Press.

Yoo, Y. 1997. Han-Laden women: Korean "comfort women" and women in Judges 19-21, in Reading the bible as women: Perspectives from Africa, Asia, and Latin America, edited by P.A. Bird. Atlanta, Ga.: SBL:37-46.

Ziervogel, D. and Mokgokong, P.C. 1975. Comprehensive Northern Sotho dictionary. Pretoria: Van Schaik. 